\title{
Effect of Cone-beam Computed Tomography on Treatment Decision of Wisdom Tooth
}

\author{
Konik Işınlı Bilgisayarlı Tomografinin Yirmi Yaş Dişin Tedavi \\ Kararına Etkisi
}

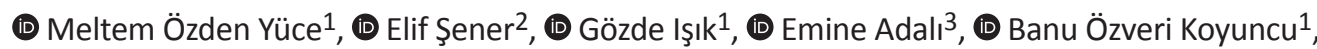 \\ (1) Bedriye Güniz Baksı², (1) Ceyda Gürhan ${ }^{4}$

\footnotetext{
${ }^{1}$ Ege University Faculty of Dentistry, Department of Oral and Maxillofacial Surgery, İzmir, Turkey

${ }^{2}$ Ege University Faculty of Dentistry, Department of Oral and Maxillofacial Radiology, Izmir, Turkey

${ }^{3}$ Izmir Democracy University Faculty of Dentistry, Department of Oral and Maxillofacial Surgery, İzmir, Turkey

${ }^{4}$ Acıbadem Health Group Altunizade Hospital, Clinic of Oral and Dental Health, İstanbul, Turkey
}

Keywords

Cone-beam computed tomography, threedimensional imaging, mandibular canal, diagnostic accuracy

\section{Anahtar Kelimeler}

Konik ışınlı bilgisayarlı tomografi, üç boyutlu görüntüleme, mandibular kanal, tanısal doğruluk

Received/Geliş Tarihi : 15.10 .2020

Accepted/Kabul Tarihi : 23.12.2020

doi:10.4274/meandros.galenos.2020.59002

Address for Correspondence/Yazışma Adresi: Meltem Özden Yüce MD,

Ege University Faculty of Dentistry,

Department of Oral and Maxillofacial Surgery, İzmir, Turkey

Phone : +90 2323112809

E-mail : meltemozdn@hotmail.com

ORCID ID: orcid.org/0000-0002-7088-9701

(C) Meandros Medical and Dental Journal, Published by Galenos Publishing House.

This is article distributed under the terms of the

Creative Commons Attribution NonCommercial 4.0

International Licence (CC BY-NC 4.0).

\begin{abstract}
Objective: This diagnostic accuracy study aimed to evaluate the relationship between mandibular third molars (M3) and mandibular canal (MC) using panoramic radiographs (PR) and cone-beam computed tomography (CBCT) and to assess the effect of CBCT on treatment decision.

Materials and Methods: CBCT scans of 150 patients with close association between $\mathrm{MC}$ and M3 on PR were included in the study. The degree of superimposition, Buccolingual position (buccal, central and lingual) and physical relationship (separation, contact and involved) were measured on CBCT images. Fisher's Exact test was used to evaluate differences between PR and CBCT.

Results: All M3 were directly superimposed on the MC on PR; however, CBCT showed separation from the canal in 10\% of M3 roots. Evaluation of CBCT images revealed that the probability to observe an involvement was significantly higher when the MC was in the lingual position (57.6\%) than in other positions.

Conclusion: Three-dimensional imaging is very useful to clarify the true relationship between $\mathrm{M} 3$ and $\mathrm{MC}$ relative to two-dimensional panoramic images, and the clinician may decide to change the treatment plan based on CBCT images in patients with high risk. Nevertheless, PR can be considered an acceptable diagnostic method with low radiation dose compare with CBCT.
\end{abstract}

Öz

Amaç: Bu tanısal doğruluk çalışmasının amacı, mandibular üçüncü molar (M3) dişler ile mandibular kanal (MK) arasındaki ilişkiyi panoramik radyografi (PR) ve konik ışınlı bilgisayarlı tomografi (KIBT) kullanarak incelemek ve KIBT'nin tedavi kararına etkisini değerlendirmektir.

Gereç ve Yöntemler: Çalışmaya, MK ile M3 arasında yakın ilişki bulunan 150 hastanın KIBT taramaları dahil edildi. KIBT'de üst üste binme derecesi, Bukko-lingud pozisyon (bukkal, merkez ve lingual) ve fiziksel ilişki (ayrı, temas ve dahil) ölçüldü. PR ve KIBT arasındaki farklar için Fisher's Exact testi kullanıldı.

Bulgular: PR üzerinde, tüm M3'ler MK ile ilişsili görüldü. Ancak, KIBT, M3 köklerinin \%10'unun kanalla ilişkisi olmadığını gösterdi. KIBT görüntülerinin değerlendirilmesi 
gösterdi ki, MK lingual pozisyonundayken $(\% 57,6)$, diğer pozisyonlar ile karşılaştıııldığında, dahil tip ilişkinin görülme olasılığı belirgin biçimde yüksekti.

Sonuç: Üç boyutlu görüntüleme, iki boyutlu panoramik görüntüleme ile karşılaştırıldığında, M3 ve MK arasındaki gerçek ilişkiyi açıklamak için oldukça kullanışılıı. Ayrıca klinisyen, yüksek riskli hastalarda KIBT görüntülerine dayalı olarak tedavi planını değiştirmeye karar verebilir. Bununla birlikte, KIBT'ye kıyasla düşük radyasyon dozu ile PR, kabul edilebilir bir teşhis yöntemi olarak düşünülebilir.

\section{Introduction}

Surgical removal of impacted lower third molars (LM3) is one of the most common procedures carried out in oral and maxillofacial surgery (1-4). As a result of close proximity of the root apices of LM3 and the mandibular canal $(\mathrm{MC})$, this surgical procedure carry the risk of inferior alveolar nerve injury (IANI) $(5,6)$. In some cases neurological complications such as paresthesia may occur, characterized by temporary or permanent numbness or unexpected sensation in the lower jaw, mental region and lower lip of the affected side, significantly disturbing the patient's quality of life $(3,7,8)$. Therefore, it is very important to evaluate the risk and inform the patients about this undesirable complication prior to surgery.

In clinical practice, panoramic radiography $(P R)$ is the imaging modality most commonly used by oral and maxillofacial surgeons to view impacted LM3 and to estimate the risk of IANI. Darkening of the root apices, loss of the cortical border of $M C$ and defected roots have been reported to be significant radiographic signs for risk of IANI $(9,10)$. However, it was clearly demonstrated that two-dimensional (2D) panoramic imaging fails to demonstrate the Buccolingual relationship of tooth roots and $M C(4,10,11)$. Even with definitive radiographic markers, threedimensional (3D) imaging is particularly recommended to establish the exact relationship between the two structures and to minimize the risk of IANI $(4,8,10,12)$. Cone-beam computed tomography (CBCT) have been advocated as a 3D imaging method of choice for the imaging of LM3 and adjacent anatomical structures, which offers lower radiation dose and high image quality (13). Studies evaluating the risk assesment of IANI using various imaging modalities demonstrated that significantly more patients were re-classified to a lower risk of injury after CBCT examination $(14,15)$. However, recent studies reported contradictory results regarding the advantages of CBCT on diagnostic accuracy, diagnostic thinking and treatment outcomes
(16-18). In general, few studies have validated the effect of accuracy of anatomical relationship of LM3 with various imaging methods and its relevance to IANI $(19,20)$.

In the present study, it was hypothesized that, if there is an increased risk of IANI, the diagnostic accuracy of $\mathrm{CBCT}$ examination contributes to more accurate and comprehensive presurgical planning by assesing the location and morphologic characteristics of the $\mathrm{MC}$ before surgery and additional pre-operative $\mathrm{CBCT}$ imaging has an effect on treatment decision. Therefore, the aim of this study was to evaluate the relationship between $\mathrm{LM} 3$ and the $\mathrm{MC}$ using $\mathrm{PR}$ and CBCT and to assess the impact of CBCT on treatment decision.

\section{Materials and Methods}

\section{Study Design and Patient Selection}

A total of 312 patients who were referred to oral and maxillofacial radiology and oral and maxillofacial surgery departments for the extraction of LM3 from September 2017 through November 2018, were examined as high risk for IANI due to third molars' being directly superimposed on the canal on 2D panoramic images.

The inclusion criteria to the study sample were the presence of overlapping between LM3 and MC on pre-operative panoramic radiographs. Patients with aforementioned radiographic relationship were considered to be associated with a high risk for IANI and nominated for CBCT examination to determine the further anatomical details. Patients with neurological diseases( $n=13)$, mandibular third molars with incomplete root formation ( $n=103)$, displacement of the root due to pathology such as cyst or tumor $(n=27)$ and declined to participate $(n=19)$ were excluded from the study (Figure 1). Therefore; the study group consisted a total of 150 patients (101 females and 49 males). Before participation, the aim and procedures were detailed and a written consent was signed in 
accordance with the Declaration of Helsinki to all participants. All patients signed constent forms that included details regarding the surgery and possible complications.

The study protocol was approved by the Ethics Committee of the Ege University Faculty of Medicine Clinical Research Ethics Committee (decision no: 155.2/4, date: 15.06.2015).

The study variables were classified as demographic data, PR and CBCT images. The demographic data included age and sex of the patient. The panoramic images were evaluated for the angulation of the impacted tooth and vertical relationship between the $\mathrm{LM} 3$ and MC. The CBCT images were used to delineate the Bucco-lingual position of the $\mathrm{MC}$ as regards to the impacted LM3 as well as the physical relationship of the root(s) of LM3 and MC.

\section{Radiographic Procedures}

PR were obtained using the OP 100 (GE Healthcare, Tuusula, Finland) panoramic X-ray unit at 70 kV, $16 \mathrm{~mA}$ and $17.6 \mathrm{~s}$. CBCT acquisition of each patient was done with the Kodak 9000 3D (Kodak Carestream Health,
Trophy, France) system operating at $70 \mathrm{kVp}$ and $10 \mathrm{~mA}$ with $2.5 \mathrm{~mm}$ Al equivalent filtration. CBCT acquisition of each patient was completed after a single $360^{\circ}$ rotation with $10.8 \mathrm{~s}$ scan time, and a volume with a spatial resolution of $76 \mu \mathrm{m}$ ( $50 \times 37 \mathrm{~mm}$ field of view) was reconstructed. The same operator took all images.

Evaluation of Panoramic and Cone-beam Computed Tomography Images

The angulation of an impacted LM3 was evaluated using Winter's classification with reference to the angle formed between the intersected longitudinal axes of the second and third molars (The vertical impaction $\left(10^{\circ}\right.$ to $\left.-10^{\circ}\right)$, mesioangular impaction $\left(11^{\circ}\right.$ to $\left.79^{\circ}\right)$, horizontal impaction $\left(80^{\circ}\right.$ to $\left.100^{\circ}\right)$ and distoangular impaction $\left(-11^{\circ}\right.$ to $\left.-79^{\circ}\right)(21)$.

The vertical relationship of LM3 apices and the MC was classified according to the superimposition degree on the panoramic radiograph (7). Following criteria was used for the classification;

Class A; root apex of the impacted LM3 superimposed on less than one third of the MC

Class B; root apex of the impacted LM3 superimposed on one third- two thirds of the MC

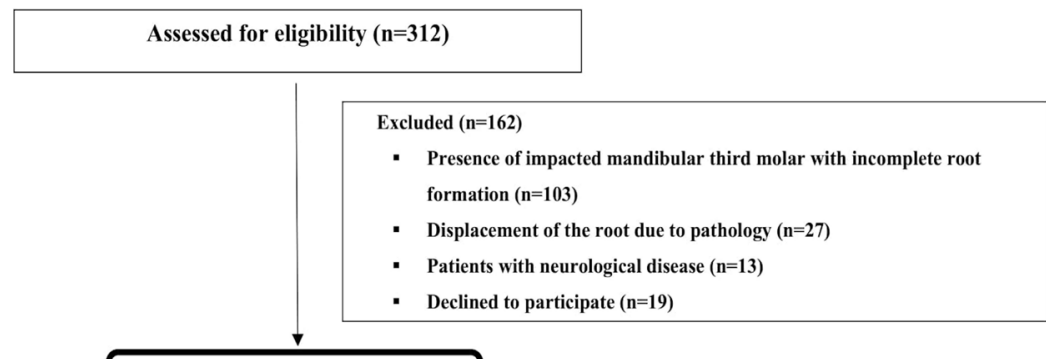

Non-Randomized Study

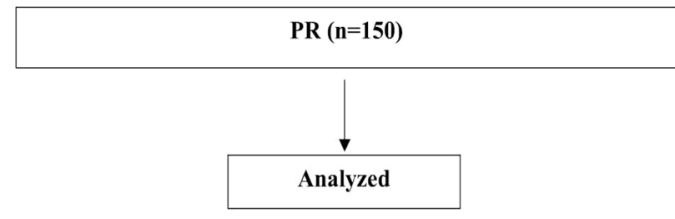

- The vertical relationship of LM3 apices and the IAC was classified according to the superimposition degree

- The angulation of an impacted LM3 was evaluated using Winter's classification

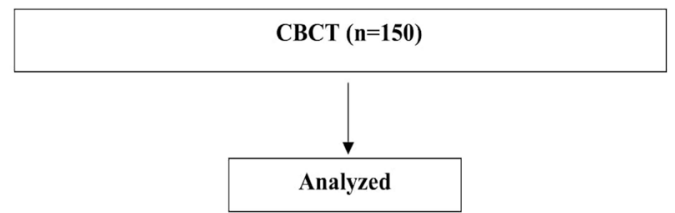

- The bucco-lingual position of the IAC as regards to the root of the impacted LM3

- The physical relationship of the IAC and the roots of impacted LM3 was classified

Figure 1. Detailed workflow diagram for excluded and included participants PR: Panoramic radiography, CBCT: Cone-beam computed tomography, LM3: Lower third molars, IAC: Inferior alveolar canal 
Class C; root apex of the impacted LM3 superimposed on more than two thirds of the $M C$ (Figure 2).

The Bucco-lingual position of the $M C$ as regards to the root of the impacted LM3 on CBCT was determined using cross sectional images with the dedicated software of the imaging system (Kodak Dental Imaging software, v.6.11.6.2, 3D module v.2.1) and classified as; lingual, buccal, inter-radicular or inferior position (Figure 3) (21).

The physical relationship of the $\mathrm{MC}$ and the roots of impacted LM3 was classified as (Type I) separated, (Type II) contact or (Type III) involved (7) (Figure 4).
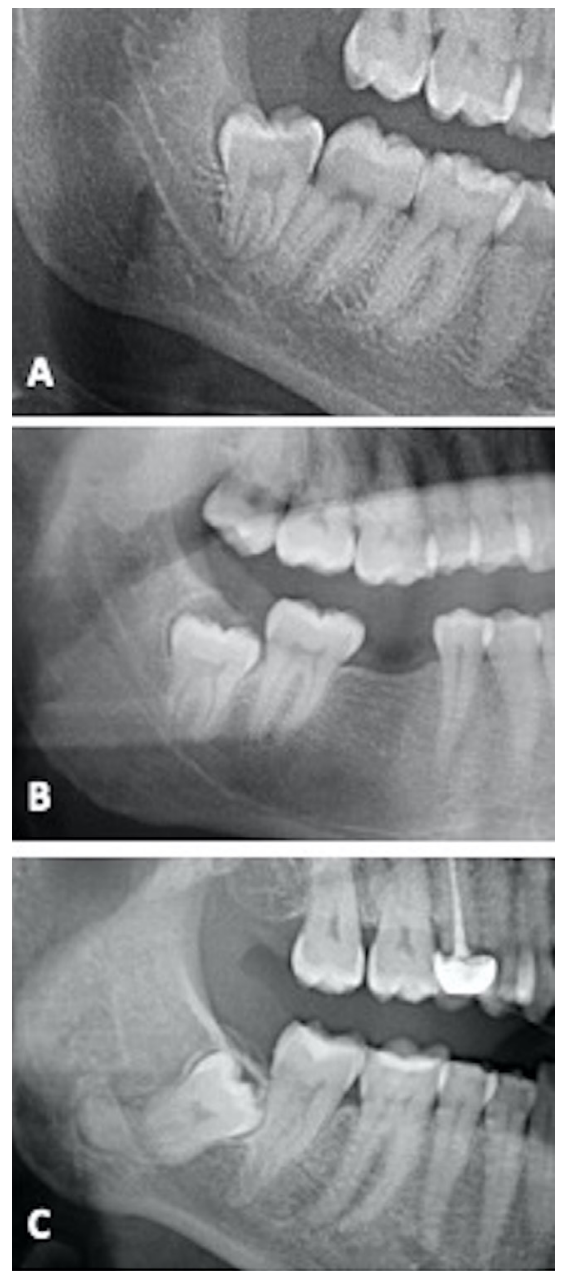

Figure 2. The vertical relationship between the lower third molars (LM3) root and the inferior alveolar canal (IAC) was classified according to the degree of superimposition on the panoramic image (a) Root apex of the impacted LM3 superimposed on less than one third of the IAC (class A) (b) Root apex of the impacted LM3 superimposed on one thirdtwo thirds of the IAC (class B) (c) Root apex of the impacted LM3 superimposed on more than two thirds of the IAC (class $C$ )
The presence of cortication around the MC was also evaluated on axial and coronal slices of CBCT images.

\section{Surgical Procedure}

Before surgery, each patient was informed of the necessity to obtain a CBCT examination and the possible complications of surgery including the potential risk of IANI. The same surgeon with 8 years
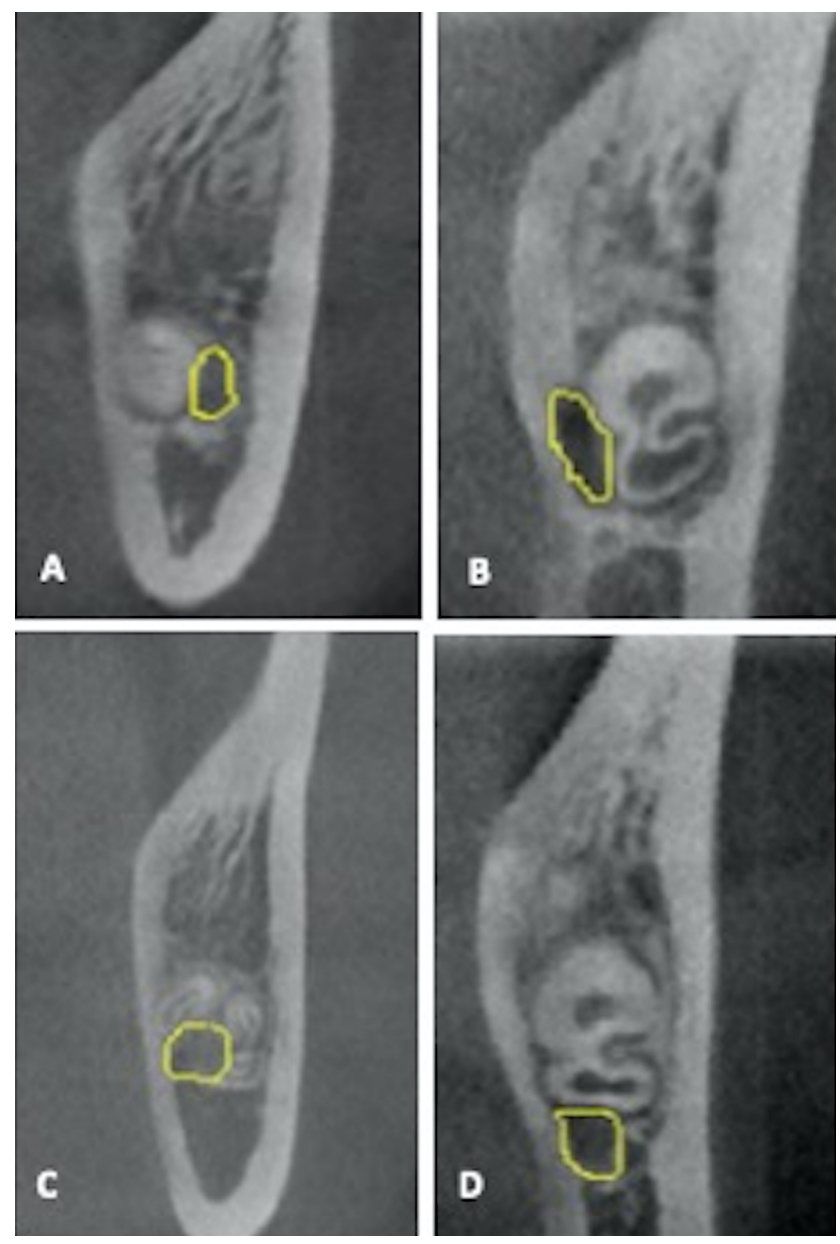

Figure 3. The Bucco-lingual position of the inferior alveolar canal as regards to the root of the impacted lower third molars classified as (a) lingual, (b) buccal, (c) inter-radicular, (d) inferior position

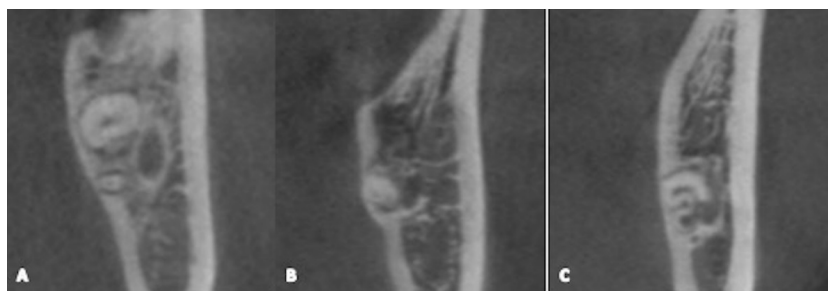

Figure 4. The physical relationship of the inferior alveolar canal and the roots of impacted lower third molars was classified as (a) separated, (b) contact, (c) involved 
of experience conducted all surgical procedures. Surgical procedures were done under local anaesthesia (Ultracaine DS Forte, Sanofi-Aventis; articaine hydrochloride 4\%; epinephrine, 1:100,000). Seperated and contact type of impacted LM3 $(n=65)$ were removed by using similar rotary instruments under continious irrigation with sterile saline solution. If there are 2 or more roots, the tooth was sectioned carefully. After the removal of the tooth the socket was cleaned and the area was primarily closed.

Coronectomy (partial odontectomy) technique was performed in involved type of impacted LM3 $(n=85)$; the crown of the tooth removed by using the same rotary instruments under continuous irrigation as mentioned above and after removal of the crown, the surface was lowered 2-3 mm under bone margin. The roots were leaved in place and the area was primarily closed.

Postoperatively, amoxicillin (1000 mg twice per day for five days), $0.2 \%$ chlorhexidine mouthwash (twice per day for seven days) and ibuprofen (400 mg four times per day for five days) were prescribed to all patients.

\section{Neurosensory Disturbance Assessment}

Post-operative sensory function was evaluated by two-point discrimination neurosensory test at various time intervals after surgery.

The follow-up examinations were done at regular intervals; the following day, 1 week and 1, 3, 6 months after surgery. Patients were questioned about the presence of any sensory change or disturbance in the lower jaw, mental region and lower lip of the operation side such as paresthesia or numbness. When the above-mentioned symptoms were recovered within 6 months it was defined as a transient, but when there is no recovery within 6 months after surgery it was defined as permanent injury.

\section{Statistical Analysis}

The statistical analysis was performed using the Statistical Package for the Social Sciences version 20.0 (SPSS, IBM Corp., Armonk, NY, USA). The relation between predictor variables among the categories on panoramic and CBCT images and outcome factors was analyzed using the Fisher's Exact test. $\mathrm{P}<0.05$ was considered statistically significant.

\section{Results}

One hundred fifty third molars, which had a close relationship with MC in PR from 150 patients (101 female, 49 male), were included in the study. The mean age of the patients was 29.71 years ranging between $18-78$ years (Table 1 ).

Mesioangular impaction showed the highest prevalence with $62 \%$ ratio followed by vertical $(22 \%)$, horizontal (10.7\%) and distoangular impaction (5.3\%). The prevalence and classification of impaction of LM3 did not show any significant difference between male and female patients ( $p>0.05$ ).

Vertical relationship between the root apices of the impacted third molars and the $M C$ evaluated using PR showed that $73.3 \%$ of the molars have class A relationship while $23.3 \%$ and $3.3 \%$ have class $B$ and class $C$ type of relationship. Evaluation of coronal slices for Bucco-lingual relationship showed that 39.3\% of the MCs were at the lingual side of the impacted tooth, while $30 \%$ were at the buccal side. Moreover, CBCT evaluation demonstrated that $26 \%$ and $4.6 \%$ of the MCs were in inferior and inter-radicular position respectively (Table 2 ). The percentage of panoramic images showing direct superimposition of impacted third molar apices on the inferior alveolar canal (IAC) (class A-C) was $100 \%$, but on the contrary CBCT findings revealed that only $56.67 \%$ of the roots had involved with $33.33 \%$ showing direct contact and $10 \%$ showing seperate type of relationship with the MC (Table 3).

Evaluation of the CBCT images revealed that the probability to observe involved type of relationship was significantly higher when the $M C$ was in the lingual position (57.6\%) as compared to the other positions $(p<0.05)$.

Transient paresthesia was observed in two patients as a post-operative complication. Both patients' LM3 had contact type of relationship with the MC and they had undergone total extraction. MC was in the lingual position in both patients with complication.

\begin{tabular}{|l|l|l|l|}
\hline \multicolumn{4}{|l|}{ Table 1. Age and sex of the patients } \\
\hline Age (years) & Male & Female & Total \\
\hline$<25$ & 20 & 52 & 72 \\
\hline $25-40$ & 18 & 39 & 57 \\
\hline$>40$ & 11 & 10 & 21 \\
\hline Total & 49 & 101 & 150 \\
\hline
\end{tabular}




\begin{tabular}{|c|c|c|c|c|c|}
\hline \multirow{2}{*}{$\begin{array}{l}\text { СВСТ } \\
\text { physical relationship }\end{array}$} & \multirow{2}{*}{$\begin{array}{l}\text { СВCT } \\
\text { Bucco-lingual position }\end{array}$} & \multicolumn{3}{|c|}{ Degree of superimposition on panoramic radiography images } & \multirow[b]{2}{*}{ Total } \\
\hline & & Class A & Class B & Class C & \\
\hline \multirow{5}{*}{ Separated } & Buccal & 8 & 2 & 0 & 10 \\
\hline & Inferior & 4 & 0 & 0 & 4 \\
\hline & Lingual & 0 & 1 & 0 & 1 \\
\hline & Interradicular & 0 & 0 & 0 & 0 \\
\hline & Subtotal & 12 & 3 & 0 & 15 (10.00\%) \\
\hline \multirow{5}{*}{ Contact } & Buccal & 14 & 4 & 2 & 20 \\
\hline & Inferior & 11 & 4 & 0 & 15 \\
\hline & Lingual & 6 & 3 & 0 & 9 \\
\hline & Interradicular & 6 & 0 & 0 & 6 \\
\hline & Subtotal & 37 & 11 & 2 & 50 (33.33\%) \\
\hline \multirow{5}{*}{ Involved } & Buccal & 10 & 4 & 1 & 15 \\
\hline & Inferior & 18 & 1 & 1 & 20 \\
\hline & Lingual & 33 & 15 & 1 & 49 \\
\hline & Interradicular & 0 & 1 & 0 & 1 \\
\hline & Subtotal & 61 & 21 & 3 & 85 (56.67\%) \\
\hline \multicolumn{2}{|l|}{ Total } & $110(73.30 \%)$ & 35 (23.30\%) & 5 (3.30\%) & $150(100.00 \%)$ \\
\hline \multicolumn{6}{|c|}{ СВCT: Cone-beam computed tomography } \\
\hline
\end{tabular}

Table 3. Proximity between third molars and the inferior alveolar canal in panoramic radiography and cone-beam computed tomography images

\begin{tabular}{|l|l|l|l|} 
& Class A (\%) & Class B (\%) & Class C (\%) \\
\hline Separated & $12(10.9)$ & $3(8.6)$ & $0(0)$ \\
\hline Contact & $37(33.6)$ & $11(31.4)$ & $2(40)$ \\
\hline Involved & $61(55.5)$ & $21(60)$ & $3(60)$ \\
\hline Total & 110 & 35 & 5 \\
\hline
\end{tabular}

\section{Discussion}

Radiographic evaluation is of paramount importance to reduce the possible postoperative risks and complications of surgical extraction of mandibular third molars. Meticulous pre-operative radiographic examination prevents many post-operative complications such as pain, swelling, bleeding, infection, alveolitis, trismus, fracture and injury to the IAN, buccal and lingual nerve $(10,11,22)$. IANI is the most serious and unpleasant complication that arise from third molar surgery which usually causes medicolegal problems and functional problems as well as decreased quality of life.
Pre-operative radiographic evaluation should be discriminating and should provide information about the location of the tooth in relation to the neigbouring roots and vital anatomical structures as well as the position, depth and the type of impaction of the third molars. However, if the relationship between the apices of impacted third molar and the IAN is not clear on 2D panoramic radiographs, 3D imaging is indicated for accurate preoperative assessment $(1,4,23,24)$. European Commision guidelines as well as the position paper of the European Academy of Dentomaxillofacial Radiology suggest using CBCT only when the surgeon has a very specific clinical 
question that cannot be answered by conventional 2D imaging (23). Accordingly, in the present study only patients requiring comprehensive evaluation were referred for further evaluation with CBCT in order to avoid any complications and change the treatment modality. According to the results obtained CBCT findings revealed $56.67 \%$ of the roots had involved type relationship with IAC, even though all third molar roots were seen as directly superimposed on the canal on 2D panoramic images. Therefore, it was once again proved that $3 \mathrm{D}$ accurate determination of the proximity of IAC and impacted third molar roots is mandatory. It was previously claimed that the most important parameter for the assesment of proximity of mandibular M3 apices to the IAC was not only the Bucco-lingual position of IAC relative to third molars, but also physical relationship between the LM3 roots and inferior alveolar canal (25). Furthermore, the location of third molar root apices with the IAC (inside or in contact) was suggested to be a more important parameter for the IANI risk evaluation (7).

Coronectomy technique was first introduced in 1989 by Knuttson et al. (26) to avoid IANI in high risk patients. Since its introduction, numerous studies have reported the benefits and limitations of this technique; the excessive advantages of the technique in high risk patients makes the technique a favorable option in maxillofacial surgery practice (27-31). Coronectomy is a widely accepted alternative treatment modality which can reduce the risk of IANI compared with complete surgical removal when treating high-risk LM3. Pedersen et al. (29) reported a good long-term prognosis of coronoctomy treatment in 231 mandibular third molar coronoctomies and stated the surgical procedure as a safe technique. Similarly, in their research both Leung and Cheung (32) and Renton et al. (33) reported that coronectomy technique was associated with a low incidence of nerve damage compared with surgical removal of mandibular third molars. Also, Monaco et al. (30) reported low rate of postoperative complications in coronectomy technique. Based on these data; due to CBCT enables accurate surgical planning; in the present study patients with the presence of overlapping between LM3 and IAC on pre-operative panoramic radiographs were referred to additional $\mathrm{CBCT}$ and the treatment modality changed from total extraction to coronectomy in 85 patients.
It was previously demonstrated that the mesioangular impaction is the most common angulation of impacted mandibular third molars. However, studies evaluating the effect of angulation type on prevalance of IANI showed that the highest risk of nerve injury was observed when the tooth was impacted in either distoangular or horizontal position (25). The high number of mesioangular impacted third molars included to the present study may be the possible reason of low incidence of IANI in the total extraction group.

Although there are contradictory results, buccal course of MCs were predominant in many reports $(20,25,34)$. Supplementary to this finding, utilizing a buccal technique through the entire mandibular thickness was advised for most third molar surgeries $(22,25)$. However, according to the results obtained in the present study most of the MCs were positioned lingual to the impacted third molars similar to the report of Ohman et al. (35) Consequently, the high incidence of lingual position of MCs and removal of impacted mandibular third molars by buccal surgical technique may be another reason for low incidence of IANI for this study.

The radiation burden of CBCT should always be considered and as recommended by recent position paper CBCT should only be used if it will change the treatment plan or treatment outcome for the patient (36). Otherwise, two dimensional images can be considered an acceptable diagnostic methods with lower effective doses, to compare with CBCT images. Furthermore, the sample size for this study was small which may be regarded as a limitation to this study, therefore; further studies with a large group of patients are needed to generalise the findings.

\section{Conclusion}

It is possible to conclude that 3D imaging did not influence the prevalence of IANI but provided better deliniation of the relationship between impacted molar tooth roots and surrounding vital structures as compared to 2D panoramic images. However, given the radiation burden of $\mathrm{CBCT}$, PR can be considered an acceptable diagnostic method with low radiation dose. Therefore, CBCT should only be used for risk assessment; when a direct anatomical relationship between the LM3 and MC was observed on PR, thus the surgeon can change the treatment plan before the surgery. 


\section{Ethics}

Ethics Committee Approval: The study protocol was approved by the Ethics Committee of the Ege University Faculty of Medicine Clinical Research Ethics Committee (decision no: 15-5.2/4, date: 15.06.2015).

Informed Consent: Before participation, the aim and procedures were detailed and a written consent was signed in accordance with the Declaration of Helsinki to all participants.

Peer-review: Externally and internally peerreviewed.

\section{Authorship Contributions}

Concept: M.Ö.Y., E.Ş., G.I., E.A., B.Ö.K., B.G.B., C.G., Design: M.Ö.Y., E.Ş., G.I., E.A., B.Ö.K., B.G.B., C.G., Supervision: M.Ö.Y., E.Ş., G.I., E.A., B.Ö.K., B.G.B., C.G., Fundings: M.Ö.Y., E.Ş., G.I., E.A., B.Ö.K., B.G.B., C.G., Materials: M.Ö.Y., G.I., E.A., Data Collection or Processing: M.Ö.Y., G.I., E.A., Analysis or Interpretation: M.Ö.Y., E.Ş., E.A., Literature Search: M.Ö.Y., G.I., E.A., Critical Review: M.Ö.Y., E.Ş., G.I., E.A., B.Ö.K., B.G.B., C.G., Writing: M.Ö.Y., E.Ş., G.I., E.A., B.Ö.K., B.G.B., C.G.

Conflict of Interest: No conflict of interest was declared by the authors.

Financial Disclosure: The authors declared that this study received no financial support.

\section{References}

1. Peixoto LR, Gonzaga AK, Melo SL, Pontual, ML, Pontual Ados $A$, de Melo DP. The effect of two enhancement tools on the assessment of the relationship between third molars and the inferior alveolar canal. J Craniomaxillofac Surg 2015; 43: 637-42.

2. Huang CK, Lui MT, Cheng DH. Use of panoramic radiography to predict postsurgical sensory impairment following extraction of impacted mandibular third molars. J Chin Med Assoc 2015; 78: 617-22.

3. Sinha P, Pai A. Assessment of proximity of impacted mandibular third molar roots to the mandibular canal using intra oral periapical radiography and cone-beam computerized tomography: A comparative study. Int Dental Medical J Advanced Research 2015; 1: 1-5.

4. Peker I, Sarikir C, Alkurt MT, Zor ZF. Panoramic radiography and cone-beam computed tomography findings in preoperative examination of impacted mandibular third molars. BMC Oral Health 2014; 14: 71.

5. Umar G, Obisesan O, Bryant C, Rood JP. Elimination of permanent injuries to the inferior alveolar nerve following surgical intervention of the "high risk" third molar. Br J Oral Maxillofac Surg 2013; 51: 353-7.
6. Selvi F, Dodson TB, Nattestad A, Robertson K, Tolstunov L. Factors that are associated with injury to the inferior alveolar nerve in high-risk patients after removal of third molars. Br J Oral Maxillofac Surg 2013; 51: 868-73.

7. Xu GZ, Yang C, Fan XD, Yu CQ, Cai XY, Wang Y, et al. Anatomic relationship between impacted third mandibular molar and the mandibular canal as the risk factor of inferior alveolar nerve injury. Br J Oral Maxillofac Surg 2013; 51: 215-9.

8. Palma-Carrió C, Garcia-Mira B, Larrazabal-Morón CL, PenarrochaDiago M. Radiographic signs associated with inferior alveolar nerve damage following lower third molar extraction. Med Oral Patol Oral Cir Bucal 2010; 15: 886-90.

9. Sedaghatfar M, August MA, Dodson TB. Panaromic radiographic findings as predictors of inferior alveolar nerve exposure following third molar extraction. J Oral Maxillofac Surg 2005; 63: 3-7.

10. Jun $\mathrm{SH}, \mathrm{Kim} \mathrm{CH}$, Ahn JS, Padwa BL, Kwon JJ. Anatomical differences in lower third molars visualized by 2D and 3D X-ray imaging: clinical outcomes after extraction. Int J Oral Maxillofac Surg 2013; 42: 489-96.

11. Dalili Z, Mahjoub P, Sigaroudi AK. Comparison between cone beam computed tomography and panoramic radiography in the assessment of the relationship between the mandibular canal and impacted class $C$ mandibular third molars. Dent Research 2011; 8: 203-10.

12. Mela OA, Tawfik MAM, Mansour NA. Assessment of the relationship between the mandibular canal and impacted third molars using cone beam computed tomography. Mansoura J Dent 2014; 1: 49-55.

13. Nardi C, Talamonti C, Pallotta S, Saletti P, Calistri L, Cordopatri C. Head and neck effective dose and quantitative assessment of image quality: a study to compare cone beam CT and multislice spiral CT. Dentomaxillofac Radiol 2017; 46: 20170030.

14. Juodzbalys G, Wang HL. Guidelines for the Identification of the Mandibular Vital Structures: Practical Clinical Applications of Anatomy and Radiological Examination Methods. J Oral Maxillofac Res 2010; 1: 1.

15. Ghaeminia H, Meijer GJ, Soehardi A, Borstlap WA, Mulder J, Vlijmen OJ, et al. The use of cone beam CT for the removal of wisdom teeth changes the surgical approach compared with panoramic radiography: a pilot study. Int J Oral Maxillofac Surg 2011; 40: 834-9.

16. Petersen LB, Christensen J, Olsen K, Wenzel A. Image and surgery-related costs comparing cone beam $\mathrm{CT}$ and panoramic imaging before removal of impacted mandibular third molars. Dentomaxillofac Radiol 2014; 43: 20140001.

17. Matzen LH, Petersen LB, Wenzel A. Radiographic methods used before removal of mandibular third molars among randomly selected general dental clinics. Dentomaxillofac Radiol 2016; 45 : 20150226.

18. Clé-Ovejero A, Sánchez-Torres A, Camps-Font O, Gay-Escoda C, Figueiredo R, Valmaseda-Castellón E. Does 3-dimensional imaging of the third molar reduce the risk of experiencing 
inferior alveolar nerve injury owing to extraction? A metaanalysis. J Am Dent Assoc 2017; 148: 575-83.

19. Tachinami H, Tomihara K, Fujiwara K, Nakamori K, Noguchi M. Combined preoperative measurement of three inferior alveolar canal factors using computed tomography predicts the risk of inferior alveolar nerve injury during lower third molar extraction. Int J Oral Maxillofac Surg 2017; 46: 1479-83.

20. Wang $D$, Lin $T$, Wang $Y$, Sun $C$, Yang L, Jiang $H$, et al. Radiographic features of anatomic relationship between impacted third molar and inferior alveolar canal on coronal CBCT images: risk factors for nerve injury after tooth extraction. Arch Med Sci 2018; 14: 532-40.

21. Hasegawa T, Ri S, Shigeta $T$, Akashi M, Imai $Y$, Kakei $Y$, et al. Risk factors associated with inferior alveolar nerve injury after extraction of the mandibular third molar-a comparative study of preoperative images by panoramic radiography and computed tomography. Int J Oral Maxillofac Surg 2013; 42: 843-51.

22. Manor $Y$, Abir R, Manor A, Kaffe I. Are different imaging methods affecting the treatment decision of extractions of mandibular third molars? Dentomaxillofac Radiol 2016; 18: 20160233.

23. Adibi S, Paknahad M. Comparison of cone-beam computed tomography and osteometric examination in preoperative assessment of the proximity of the mandibular canal to the apices of the teeth. Br J Oral Maxillofac Surg 2017; 55: 246-50.

24. Korkmaz YT, Kayıpmaz S, Senel FC, Atasoy, KT, Gumrukcu Z. Does additional cone beam computed tomography decrease the risk of inferior alveolar nerve injury in high-risk cases undergoing third molar surgery? Does CBCT decrease the risk of IAN injury? Int J Oral Maxillofac Surg 2017; 46: 628-35.

25. Juodzbalys G, Daugela P. Mandibular third molar impaction: review of literature and a proposal of a classification. J Oral Maxillofac Res 2013; 4: 1.

26. Knuttson K, Lysell L, Rohlin M. Postoperative status after partial removal of the mandibular third molar. Swed Dent J 1989; 13: $15-22$.

27. Dalle Carbonare M, Zavattini A, Duncan M, Williams M, Moody A. Injury to the inferior alveolar and lingual nerves in successful and failed coronectomies: systematic review. $\mathrm{Br} J$ Oral and Maxillofac Surg 2017; 55: 892-8.
28. Ali AS, Benton JA, Yates JM. Risk of inferior alveolar nerve injury with coronectomy vs surgical extraction of mandibular third molars-A comparison of two techniques and review of the literature. J Oral Rehabil 2018; 45: 250-7.

29. Pedersen MH, Bak J, Matzen LH, Hartlev J, Bindslev J, Schou S, et al. Coronectomy of mandibular third molars: a clinical and radiological study of 231 cases with a mean follow-up period of 5,7 years. Int J Oral Maxillofac Surg 2018; 47: 1596-603.

30. Monaco G, De Santis G, Pulpito G, Gatto MR, Vignudelli E, Marchetti C. What Are the Types and Frequencies of Complications Associated With Mandibular Third Molar Coronectomy? A Follow-Up Study. J Oral Maxillofac Surg 2015; 73: 1246-53.

31. Barcellos BM, Velasques BD, Moura LB, Xavier CB. What Are the Parameters for Reoperation in Mandibular Third Molars Submitted to Coronectomy? A Systematic Review. Oral Maxillofac Surg 2019; 77: 1108-15.

32. Leung YY, Cheung LK. Safety of coronectomy versus excision of wisdom teeth: a randomized controlled trial. Oral Surg Oral Med Oral Pathol Oral Radiol Endod 2009; 108: 821-7.

33. Renton $T$, Hankins $M$, Sproate $C$, McGurk M. A randomised controlled clinical trial to compare the incidence of injury to the inferior alveolar nerve as a result of coronectomy and removal of mandibular third molars. Br J Oral Maxillofac Surg 2005; 43: 7-12.

34. Maegawa H, Sano K, Kitagawa Y, Ogasawara T, Miyauchi K, Sekine $J$, et al. Preoperative assessment of the relationship between the mandibular third molar and the mandibular canal by axial computed tomography with coronal and sagittal reconstruction. Oral Surg Oral Med Oral Pathol Oral Radiol Endod 2003; 96: 63946.

35. Ohman A, Kivijarvi K, Blomback U, Flygare L. Pre-operative radiographic evaluation of lower third molars with computed tomography. Dentomaxillofac Radiol 2006; 35: 30-5.

36. Matzen LH, Berkhout E. Cone beam CT imaging of the mandibular third molar: a position paper prepared by the European Academy of DentoMaxilloFacial Radiology (EADMFR). Dentomaxillofac Radiol 2019; 48: 20190039. 